\title{
CHROMOSOMAL DISEASES IN THE HUMAN PATHOLOGY (review)
}

\author{
*T.V. Bihunyak, Yu.I. Bondarenko, O.O. Kulyanda, \\ S.M. Charnosh, A.S. Sverstiuk, K.O. Bihuniak \\ I. HORBACHEVSKY TERNOPIL NATIONAL MEDICAL UNIVERSITY, TERNOPIL, UKRAINE
}

\begin{abstract}
Background. Chromosomal diseases are the cause of 45-50 \% of multiple birth defects. Basic research on mutations is performed using genomic technologies to identify a correlation between genotype and phenotype in aneuploidies and to understand its pathogenesis.

Objective. The aim of the research is to study the etiology, pathogenesis of symptoms and diagnostics for patients with Down, Klinefelter, Turner syndromes and double aneuploidies by 21 and sex chromosomes.

Methods. A literature review by the keywords "Down syndrome", "Klinefelter syndrome", "Turner syndrome", "double aneuploidy" for the period of 2000-2020 was carried out.

Results. Down, Klinefelter and Turner syndromes are the most common aneuploidy among viable newborns. Frequency of meiotic non-disjunction events causing these aneuploidies increases with the age of a woman. Identified genes are responsible for pathogenesis of symptoms in trisomy 21, Turner and Klinefelter syndromes. Diagnostics of chromosomal diseases includes prenatal screening programs and postnatal testing.

Conclusions. Cytogenetic variants of Down syndrome are simple complete trisomy 21, translocation form and mosaicism. Trisomy 21 is associated with advanced maternal age. Phenotypic manifestations of Down syndrome are associated with the locus 21q22. The maternal and parental nondisjunction of X-chromosomes in meiosis causes Klinefelter and Turner syndromes. These chromosomal diseases are variants of intersexualism with intermediate chromosomal sex. Down-Klinefelter and Down-Turner syndromes are double aneuploidies. Patients have a Down syndrome phenotype at birth, and signs of Klinefelter and Turner syndromes occur during puberty. Diagnosis of aneuploidy is based on the cytogenetic investigation (karyotyping), DNA analysis, ultrasonography and biochemical markers of chromosomal pathology.
\end{abstract}

KEY WORDS: Down syndrome; Klinefelter syndrome; Turner syndrome; double aneuploidy.

\section{Introduction}

Changes in the number and structure of chromosomes take place in $1 \%$ of newborns. They are the cause of $45-50 \%$ of multiple birth defects, about $36 \%$ of cases of mental retardation, $50 \%$ of primary amenorrhea in women, and $10 \%$ of sterility in men [1]. Among all cases of birth defects in the life of stillbirths in Ukraine for 2002-2015, almost every $2^{\text {nd }}$ case referred to chromosomal pathology. The main clinical chromosomal syndromes include: Down syndrome (DS) - trisomy 21 - prevalence 1:400-1:1,500 newborns, Klinefelter syndrome (KS) - karyotype 47, XXY with a frequency of 1:500-1,000 newborn boys, Turner syndrome (TS) - karyotype $45, \mathrm{X}$ with a frequency of 1:2,000-5,000 newborn girls [2-6]. Among the viable newborns, 1 of 400 boys and 1 of 650 girls have different forms of aneuploidy by sex chromosomes. KS and TS are most common among them [7].

Double aneuploidy is a rare chromosomal abnormality detected after birth since most *Corresponding author: Bihunyak T.V., MD, Ph.D., Associate Professor, Department of Pathophysiology, I. Horbachevsky Ternopil National Medical University, Ternopil, Ukraine. E-mail: bihunyak@tdmu.edu.ua. reported cases are presented in the form of one lethal aneuploidy and end in early miscarriage. It is extremely rare to find living newborn cases with double autosomal trisomy or autosomal trisomy with sex chromosome monosomy or trisomy [8]. The most frequent co-occurrence is that of DS and KS (coincidence $0.098 \%$ ), because they are common and relatively well tolerated chromosome abnormalities in humans [9].

The frequency of mutations that causes chromosomal diseases does not depend on race or country. The dynamics of the spread of chromosomal diseases over the past two decades in the world has changed due to the discovery of new cases of double aneuploidy in viable newborns. Early prenatal diagnosis of trisomy 21 as well as postnatal aneuploidy by sex chromosomes is urgent.

Basic research on aneuploidy is conducted using genomic technologies to identify a correlation between genotype and phenotype in chromosomal diseases and to understand its pathogenesis. For diagnosis of hereditary dise- 
ases, the medical genetics methods are used, in particular cytogenetic, genealogical, dermatoglyphics, biochemical, and DNA molecular analysis. The cytogenetic method (karyotyping) is widely used for diagnosis of human chromosomal diseases. It is important to be aware of diagnostic possibilities of prenatal testing for early detection of fetal chromosomal pathology such as screening programs for women at early pregnancy. The more deeply the nature of human heredity is analyzed, the more it is realized regarding the methods of diagnostics, treatment and prevention of diseases.

The aim of the research is to study the cytogenetic mechanisms of occurrence, pathogenesis of changes in the phenotype and medical genetic counseling for patients with DS, KS and TS.

\section{Methods}

A literature review by the keywords "Down syndrome", "Klinefelter syndrome", "Turner syndrome", "double aneuploidy" for the period of 2000-2020 was carried out.

\section{Review}

According to the literature, in 1866 English physician John Landon Down identified a group of patients with dementia and peculiar somatic abnormalities and called the disease "Mongoloid idiopathy". The hypothesis of hereditary origin of the syndrome was considered questionable, although in 1932 the ophthalmologist and geneticist Waardenburg suggested that the basis of the pathology may have been "chromosomal insufficiency" [2-3]. Despite this, the cause of this syndrome was clarified only in 1959 by a French scientist Lejeune. He stated that in the karyotype of those patients there were 47 chromosomes, and a small acrocentric chromosome in the group $\mathrm{G}$ (21 or 22 ) was superfluous. As a result of development of the fluorescence chromosome identification method in 1971, it was possible to differentiate 21 of 22 chromosomes and establish the true karyotype in DS. The incidence of patients' birth with trisomy 21 is not affected by sexual, racial, geographical or population differences. The incidence of children with DS depends on the age of the mother (Table 1) [1]. More than $80 \%$ of children with trisomy 21 are born to women under 35 years of age [3]. Hence, prenatal screening and diagnosis of trisomy 21 for a fetus are important for pregnant women aged 35 years and older [10].

Cytogenetic variants of DS are diverse. However, the main part (94-95\%) is the cases of simple complete trisomy 21 as a consequence of the nondisjunction of chromosomes to the opposite poles of the cell in the anaphase I or anaphase II of the meiosis. The contribution of maternal nondisjunction is $95 \%$, and the father's only $5 \%$. No dependence on father's age was found in cases of DS where the additional chromosome originated from father. About $75 \%$ of maternal nondisjunction occur during meiosis I, and $25 \%$ - during meiosis II, but about $25 \%$ of paternal nondisjunction occur during meiosis I, and 75\% - during meiosis II [14]. As a result, gametes (oocyte or sperm) have 22 chromosomes (-21) or 24 chromosomes $(+21)$. When a normal gamete that has 23 chromosomes fuses with gametes with $24(+21)$ chromosomes, then a zygote $47,+21$ is formed, and a child with DS may be born. The karyotype of patients with this will be $47, X X,+21$ or $47, X Y,+21$ [11]. About $2-5 \%$ of patients with DS have mosaic forms due to the mitotic nondisjunction of the chromosomes after fertilization (post zygotically), in which one part of the cells has a normal amount of chromosomes (46), and the other is aneuploid (47). The karyotypes of patients with $47, \mathrm{XX},+21 / 46$ or $47, \mathrm{XY},+21 / 46[11$, 13]. The frequency of gonadal mosaicism in trisomy 21 , according to some researchers, is actually larger. Available for tissue analysis (blood lymphocytes, skin fibroblasts) have a low mosaic level, while an abnormal line is present in gonads. Study of QRQ polymorphism of chromosomes in 151 families of Down children showed that in 8 families there is gonadal mosaicism in trisomy 21 , with all cases of mothers younger than 35 years old. The frequency of carriage of mosaicism in young families was $6.5 \%$ (8/123). Approximately $4 \%$ of patients with DS have a translocation form. The patients have a diploid chromosome set, but their morphology is disturbed. This form occurs, as a rule, as a result of the Robertson translocation of surplus

Table 1. The risk of childbirth with Down syndrome in women of different age groups

\begin{tabular}{|c|c|}
\hline $\begin{array}{c}\text { Age of a woman } \\
\text { at the time of } \\
\text { childbirth, years }\end{array}$ & $\begin{array}{c}\text { Empirical risk of having } \\
\text { a baby with Down } \\
\text { syndrome }\end{array}$ \\
\hline till 19 & $1: 1640$ \\
\hline $20-24$ & $1: 1986$ \\
\hline $25-29$ & $1: 1319$ \\
\hline $30-34$ & $1: 603$ \\
\hline $35-39$ & $1: 217$ \\
\hline $40-44$ & $1: 84$ \\
\hline 45 & $1: 31$ \\
\hline
\end{tabular}


21 chromosomes between the acrocentric cells (D/21 and G/21). 25\% of translocation forms are inherited from native carriers, and $75 \%$ of the translocations are formed de novo [14-15]. The translocation form of the DS is not phenotypically different from the classic trisomy 21. The occurrence of this pathology does not depend on the age of parents, while the parents can be phenotypically healthy carriers of translocation (45,-21,t(15q21q)). Consequently, people with a well-balanced translocation have a high risk of having a child with translocation form of DS (1:3). At normal karyotype of parents, the risk of having a baby with trisomy 21 corresponds to a simple trisomy. If a patient has a translocation variant of DS, then the parent's karyotype must be explored. In young parents, who have children with DS, balanced chromosomal aberrations (1.95\%) are found in 8 times more often than in the other population. When translocation type 13/21 is revealed in the father, the risk of birth of a sick child is $2.4 \%$, and in the mother - about $10 \%$. If one of the parents has a translocation type $21 / 21$, the risk of having a baby with Down syndrome is $100 \%$. About $10 \%$ of mothers of the children with DS have mosaicism. In the case of parents' mosaicism, genetic risk should be considered about 30\% [1]. Other forms of trisomy 21 are $1 \%$ of DS. They can be caused by: a) a terminal rearrangement of chromosome 21 around the telomeric region, the final chromosome having two centromeres and satellites on both ends; b) as a component of a double aneuploidy (for example, $48, X Y Y,+21$ or $46, X,+21)[14,16]$.

Chromosome 21 is the smallest human chromosome and contains 200 to 300 genes. Analysis of the chromosome revealed 127 established genes, 98 predicted genes and 59 pseudogenes [14]. The most acceptable theory for the pathogenesis of trisomy 21 is the genedosage hypothesis, which declares that all changes are due to the presence of an extra copy of chromosome 21 within region 21q22. Molecular studies are aimed at determining the region of 21 chromosomes, which would code for phenotypic manifestations of DS. These gene products include morphogens, cell adhesion molecules, components of multi-subunit proteins, ligands and their receptors, transcription regulators and transporters. In particular, it has been found that the DYRK gene (21q22.13) is responsible for mental retardation. Surplus of this gene in mice causes defects in learning and memory. The third copy of the other APP gene (21q21.2 $21 q 21.3)$ encoding the $\beta$-amyloid synthesis causes Alzheimer's syndrome in the patients with trisomy 21 of over 40 years of age. If as a result of mutation this gene in the patients with DS is absent, the signs of Alzheimer's syndrome are not manifested [1,3]. Gart-gene is also detected in the 21 chromosome which in trisomy causes an increased level of purines in the blood of patients that is one of the causes of mental retardation [17]. By the results of expression of this gene you can control the occurrence of DS even in the embryonic period.

The complex of congenital abnormalities specific for DS causes the clinical picture "all children from one family". Pregnancy, from which patients are born, often is accompanied by toxicosis, the risk of miscarriage. In sick mothers there is an unfavorable obstetric anamnesis (miscarriages, stillborn). The average length of pregnancy is slightly lower than normal. Children with DS are born with moderate pronounced hypoplasia (mass $8-10 \%$ below average values) [18]. Craniofacial dysmorphia is manifested by brachycephaly $(81 \%)$, flat occiput (78\%), flattened face, flat bridge of nose $(52 \%)$, small short nose $(40 \%)$, large fissured tongue (50\%), open mouth (65\%), hypoplasia of the upper jaw, high palate (58\%), small lowly placed deformed ears, mongolism, epicanthus (80\%). Incorrect growth of the teeth, diastema, transverse striae on the lips are typical. In 68\% of patients, there are spots of Brushwild (light spots on the iris), $32.2 \%$ - cataract. In many patients with trisomy 21 , there is a short neck (45\%), newborn neck folds, broad fingers and palms, broad toes (70\%) [1]. Approximately 40$50 \%$ of the affected children have congenital heart diseases (CHD), one of the major causes of morbidity and mortality [19-20]. In Western European countries and the USA, endocardial cushion defect (43\%), which results in ventricular septal defect (VSD) (32\%), secundum atrial septal defect (ASD) (10\%), tetralogy of Fallot (6\%) and isolated patent ductus arteriosus (4\%) are present in this group of patients [14]. In Asia, isolated VSD has been reported to be the most common cardiac defect (40\%) [21]. A study from Korea showed that ASD was the most common defect accounting for $30.5 \%$ of DS, followed by VSD (19.3\%), patent duct arteriosus (17.5\%) and atrioventricular septal defect (9.4\%) [22]. The second type of ASD was the most common cardiac lesion in Latin America [23-24]. In Libya, the most common isolated cardiac lesion was the ASD, found in $23 \%$ of the patients [25]. Molecular studies of rare individuals with $\mathrm{CHD}$ and partial duplications of chromosome 
21 established candidate gene DSCAM, which was manifested in the heart during cardiac development [26]. About half of the atrioventricular septal defects AVSDs occur in the patients with DS [27]. In the patients with DS and complete AVSD potentially damaging variants in six genes: COL6A1, COL6A2, CRELD1, FBLN, FRZB, GATA5 were identified [28].

Immune problems are also typical in the form of immunodeficiency. Laboratory abnormalities can be revealed in both humoral and cellular immunity. DS is manifested by high incidence of leukemia. However, the children with DS have a 20 -fold greater risk for acute lymphoid leukemia and a 50-fold higher risk for myeloid leukemia compare to the children without DS [29]. Development of DS brain is associated with reduction in the neuronal number and abnormal neuronal differentiation. It has been previously reported that DS neuron degenerate subsequently and undergoes apoptosis [4]. The mental retardation with full trisomy 21 is found in almost all patients, and it is basically oligophrenia at the stage of imbecility (65-90\%). The average IQ of children 10 years old and over is only 24. In a mosaic variant of $D S$, moderate mental retardation is much more common, and normal intelligence is also possible. In the United States DS is $10 \%$ of all cases of mental retardation. DS is associated with epilepsy in $10 \%$ of cases. Hearing loss and anomalies of the vision organs is often observed in child patients, in particular, cataracts in $66 \%$ of the children over 8 years of age [1]. The patients with DS gain more weight compare to other population, and most adults with DS are overweight. Antithyroid antibodies predispose to disturbance of gametogenesis and nondisjunction of the 21 pair of chromosomes. The hypofunction of the thyroid gland in parents is a risk factor. Nowadays, cardiac surgery, vaccinations, antibiotics, thyroid hormones, leukemia therapies, and anticonvulsive drugs (e.g, vigabatrin) have significantly improved the quality of life of individuals with DS. Actually, life expectancy that was hardly 30 years in the $1960 \mathrm{~s}$ is now increasing - more than 60 years of age $[11,30]$. Oral care by dentists for the children with DS from the first months of life involve palatal plates that aim at activating and stimulating different functions, mainly for the orofacial motor function and expression, including language. This is complementary for that of speech therapists, physiotherapists, psycho-motor therapists, and pediatricians [31-32].
Reproductive capacity in DS is described in women, with $40 \%$ being ovulatory disorders. Men with this syndrome are sterile. Women with DS produce half normal eggs and half with 24 chromosomes. Consequently, the probability of zygote with trisomy 21 in women with DS is $50 \%$. As about $75 \%$ of these pregnancies are completed with spontaneous abortion, the risk to birth of a sick child is less than $50 \%$. Trisomy 21 among aborted embryos is found at a frequency of 1:40. The cytogenetic examination in children with DS is indicated with suspicious of trisomy 21 and with clinically established diagnosis, as the patient's cytogenetic characteristics from parents and their relatives are needed to predict the health of future children [1].

Diagnostics of DS includes prenatal and postnatal testing. For pregnancies, the high risk of DS is evaluated by fetal sample analysis after invasive chorionic villus sampling (CVS) and amniocentesis, and by laboratory techniques such as conventional karyotype analysis, Fluorescence in Situ Hybridization, Quantitative Fluorescence-Polymerase Chain Reaction, Multiplex Ligation Probe Assay and Array Comparative Genomic Hybridization, which are common techniques used for prenatal diagnosis of DS and each of them presenting with advantages and disadvantages. There is also a noninvasive technique for detection of trisomy 21 by analysis of extracted cell-free fetal DNA screening from maternal plasma samples [14]. The most common screening method contains the measurement of a combination of factors: advanced maternal age, multiple second trimester serum markers and second trimester ultrasonography. The first reported marker associated with DS was the thickening of the neck area. $40-50 \%$ of the affected fetuses have a thickened nuchal fold measuring $\geq 6 \mathrm{~mm}$ in the second trimester. When screening by nuchal translucency (NT), about $83 \%$ of trisomy 21 pregnancies were identified in the first trimester. Later, it was revealed that screening by a combination of maternal age, NT and bitest (PAPP-A with second trimester $\beta$-hCG) or tri-test [alpha-fetoprotein (AFP), estriol and free $\beta$-hCG] has a potential sensitivity of $94 \%$ for a $5 \%$ false positive rate $[4,33]$. However, Ruei-Yu Lan et al, reported about multicenter study of 29,137 cases that enrolled the chromosomal abnormality screening from Taipei city. The mean maternal age of screen-positive group was $34 \pm 4.2$ years old. The first trimester had 891 cases screening positive with a detection rate of $97.5 \%$ for fetal trisomy 21 and false 
positive rate of $3.5 \%$. Second-trimester had 334 cases screening positive, the detection rate and false positive rate were $33.3 \%$ and $6.4 \%$ respectively for trisomy 21 [10].

More recent advances in genomics and related technologies have resulted in development of a noninvasive prenatal screening (NIPS) test using cell-free fetal DNA sequences isolated from a maternal blood sample. Almost $5-10 \%$ of DNA in maternal serum are of fetal origin. Fetal trisomy detection by DNA-analysis from maternal blood has been done using massively parallel shotgun sequencing (MPSS). By next generation sequencing platforms, millions of amplified genetic fragments can be sequenced in parallel. MPSS detects higher relative amounts of DNA in maternal plasma from the fetal trisomy chromosome compare with reference chromosomes. Platforms differ according to whether amplified regions throughout the genome, chromosome-specific regions, or single nucleotide polymorphisms (SNPs) are the targets for sequencing [34]. Although studies are hopeful and exhibit high sensitivity and specificity with low false-positive rates, there are drawbacks to NIPS. Specificity and sensitivity are not consistent for all chromosomes; this is due to different content of cytosine and guanine nucleotide pairs. False-positive screening results take place because the sequences derived from NIPS are derived from the placenta, like in CVS they may not reflect the true fetal karyotype. Therefore, currently invasive testing is recommended for confirmation of a positive screening test and should remain as option for patients seeking a definitive diagnosis. NIPS began as a screen for only trisomy 21 (T21) and rapidly developed to include other common aneuploidies for chromosomes 13 (T13), 18 (T18), $X$, and $Y[35,36]$. Amniocentesis is the most conventional invasive prenatal diagnostic method accepted in the world. It is mostly performed to acquire amniotic fluid for karyotyping from 15 weeks onwards. Actually, amniocentesis performed before 15 weeks of pregnancy is referred to as early amniocentesis. CVS is usually performed between 11 and 13 weeks of gestation and includes aspiration or biopsy of placental villi. Amniocentesis and CVS are quite reliable but increase the risk of miscarriage up to 0.5 to $1 \%$ compare with the background risk [33].

A number of European countries have established a network of OSCAR clinics (One Step Clinic for Evaluation of Risk for Fetal Abnormalities). Clinics of "one visit" allow calculating the individual risk of a child's birth with chromosomal pathology regarding of the age of pregnancy, ultrasound and biochemical markers of chromosomal pathology. In particular, among the biochemical markers in the first trimester, the content of plasma protein-associated protein (PAPP-A) and $\beta$-chorionic gonadotropin ( $\beta$-hCG) levels are determined [18]. For non-invasive prenatal diagnosis, studies of fetal trophoblastic cells from the cervical canal of women in the first trimester of pregnancy are also used [37]. Constantly conventional karyotype from peripheral blood in postnatal period is performed to confirm diagnosis for all patients suspected with DS [14].

Polysomy by sex chromosomes has less significant pathological manifestations than aneuploidy by autosomes. It may be explained by the fact that the $Y$ chromosome contains little genes, and additional X chromosomes may be heterochromatic. Genetic intersexualism is the result of sex chromosome aneuploidies. TS and $\mathrm{KS}$ are variants of intersexualism with an intermediate sex [7].

TS $(45, X)$ is a single form of monosomy in the liveborns. Monosomy $X$ was discovered by Henry Turner in 1938 (earlier, in 1930, the description was made by Otto Ullrich). Cytogenetic syndrome 45,X was discovered by SE Ford in 1959 [5]. Clinically TS manifests itself in three directions: 1) hypogonadism, underdeveloped genital organs and secondary sexual characteristics; 2) congenital defects; 3) short stature. TS is one of the clinical forms of sexual differentiation disorders - agenesis with somatic malformations. In the reproductive system there is a lack of sexual glands (agenesis of gonads), hypoplasia of the uterus and fallopian tubes, primary amenorrhea, inadequate hair follicles in the pubic and axillary areas, underdevelopment of the mammary glands, deficiency of estrogens, and excess of pituitary gonadotropins. In children with TS, congenital malformations of the heart, vessels and the kidneys make up to $25 \%$. In newborns, the neck is short with excess skin and wing-like folds, with low neck hair growth. These patients have lymphatic edema of the feet, legs, hands and forearms. At school age, especially at the puberty period, there is a lag in the growth and development of secondary sexual characteristics. In $16-50 \%$ of cases the patients with TS are mentally retarded, prone to the lymphedema and Hashimoto's thyroiditis. It is established that if a TS patient received an $X$-chromosome from their father, they would have a higher IQ and better adaptation in so- 
ciety than that received from the mother's sex chromosome. Chromosomal anomalies in women with TS are quite different: $50 \%$ of these patients have 45 , X karyotype in blood lymphocytes, $30-40 \%$ are mosaics in most cases with a karyotype $45, X / 46, X X$, less than $45, X / 46, X Y$; $45, X / 47, X X X$. Among liveborn limited placental mosaicism is often observed. The more normal cells a fetus has the greater chance of its survival. About $10-20 \%$ of patients with TS have structural changes in the X-chromosome, which include deletion of short or long arms $(46, X, X p-; 46, X, X q-)$, isochromosomes [46,X,i $X q)$; $46, X, i(X p)]$, ring chromosomes $[46, X, R(X)]$. These varieties of chromosomal aberrations stipulate for the phenotype of patients. Molecular studies have shown that $60-80 \%$ of monosomies $X$ are due to the disappearance of the paternal sex chromosome that occur either in early mitosis during embryogenesis or in the process of meiosis. A repeated risk of birth of a sick child with TS in a family with normal parents karyotype does not exceed $1 \%$ [7]. Molecular analysis also allowed precise determining of specific genes responsible for the phenotype of TS. For example, the mutation in the SHOX gene causes low growth. This gene is localized in the distal segment of the $X$ chromosome (Xp22.33) and in the short arm of the $\mathrm{Y}$ chromosome. Consequently, this gene undergoes normal transcription being in two copies of a man and a woman. So, as the patients with TS have only one copy of this gene, they have a high probability of short stature development. According to Linglart et al. [38], hormone reposition in the patients with TS may reduce likelihood of short stature development. Webbed neck, lymphedema or coarctation of the aorta in infancy should prompt a peripheral blood karyotype to rule out TS [39]. The standard 30-cell karyotype is recommended and can detect $10 \%$ mosaicism with $95 \%$ confidence [5]. Multiple sequences adjacent to the Y-centromere should be amplified using polymerase chain reaction techniques to detect cryptic Y-material. When Y-chromosome material is present in the standard karyotype or on such additional testing (incidence of 5-12\%), prophylactic gonadectomy is still recommended by expert consensus, albeit at a lower quality of evidence, due to an increased risk (around $10 \%)$ of gonadoblastoma [39-40]. In TS fetal ovaries develop normally in the early stages of embryogenesis, but the absence of a second $\mathrm{X}$-chromosome leads to an accelerated loss of oocytes within 2 years. Spontaneous puberty has been reported in $14 \%$ of TS patients with monosomy $X$ and up to in one third of patients with mosaicism [5]. Young TS women with normal ovarian function should be counseled about fertility preservation options. Gonadotropins (especially follicle-stimulating hormone) should be monitored annually starting at about 11 years of age to confirm hypergonadotrophic hypogonadism prior to pubertal induction [6]. Anti-Müllerian hormone (AMH) and inhibin $B$ measurements have also been shown to predict ovarian insufficiency when found to be low, and $\mathrm{AMH}$ is perhaps the best indicator of ovarian reserve [41]. However, the majority of the girls with TS require induction of puberty and estrogen/progestin replacement therapy to achieve adequate breast development, uterine maturation and peak bone mass. Transdermal $17-\beta$ estradiol (TDE) is now the preferred treatment starting at age around 11-12 years old. Compared with oral estrogens, TDE is thought to be more physiologically delivery since it will avoid the first-pass effect in the liver with improved bioavailability. A recent metaanalysis showed improved whole-body bone mineral density, fasting glucose and total cholesterol with TDE therapy compare with oral estrogens [42].

$\mathrm{KS}$ is the most extensive major anomaly of sexual differentiation in men. The disease is described in 1942 by Harry Klinefelter in males with sexual retardation. In 1959, Jacobs and Strang showed the presence in these patients of a pathological karyotype. The most common cause of KS is nondisjunction of XX homologues for meiosis. Meiotic non-disjunction events causing KS are inherited maternally in $50-56 \%$ of cases (36\% occur in $1 \mathrm{st}$ and $20 \%$ in $2^{\text {nd }}$ meiosis), and paternally in $44-50 \%$ (100\% $1^{\text {st }}$ meiosis) $[43,44]$. With the age of the mother, as with DS, the probability of birth of a baby with this syndrome increases [1]. In 40-year-old mothers, ill children are born by 2-3 times more often than in 30-year-olds. Preliminary, it is established that half of cases with a karyotype 47, XXY end with spontaneous abortions. Mosaic among liveborn is observed in $15 \%$ of cases [7]. The presence of the $Y$ chromosome determines the formation of a male phenotype. Genetic imbalance due to excess $\mathrm{X}$-chromosome is manifested clinically during puberty as underdevelopment of the testicles and secondary male sexual characteristics. The presence of an extra chromosome can cause higher levels of gene expression and gene products in amounts affected by regulation at different levels, pro- 
tein degradation and modification [45]. Also, the interaction pattern of the proteins encoded by the additional chromosome can influence the severity of a trisomy. In the case of KS, $X$ chromosome inactivation (XCI) counterweights the extra amount of $X$ chromosome genes (about 2000). Still, roughly $15 \%$ of X-linked genes escape $X C I$, including genes in the two pseudoautosomal regions (PARs). A total of 22 $\mathrm{X}$ chromosome genes were deregulated in KS compare to the controls: 16 were upregulated (AKAP17A, ASMTL, CSF2RA, EIF1AX, EIF2S3, GPR82, GTPBP6, IL3RA, PLCXD1, PPP2R3B, PRKX, RP11EPO6015.3, SEPT6, SLC25A6, TMSB4X and XIST) and six were down-regulated (BEND2, BEX1, COX7B, FOXO4, NHS and TFE3). Some of these genes were expressed from PAR1: AKAP17A, ASMTL, CSF2RA, GTPBP6, IL3RA and PLCXD1, but no differentially expressed genes were observed encoded from PAR2. XCI compensates extensively for the extra $X$ chromosome gene dosage in KS males and probably increases their chances of survival compare to other aneuploidies [17].

Thus, in the patients with KS have a high stature, eunuchoidism, narrow arms and wide pelvis, subcutaneous fat development by female type, absent hair growth on the face, in the axillary areas and in the area of the pubis, sparse hair, underdeveloped testicles and their endocrine function (production of androgens) is reduced. The prevalence of androgen deficiency in the patients with KS is $79 \%$. The patients in most cases are sterile (due to azoospermia, oligospermia). Among men, who have infertility, more than $10 \%$ have an additional $X$-chromosome. Approximately one in three patients with this syndrome has gynecomastia and an increased risk of breast cancer development. This risk can be reduced by having a mastectomy. Gynecomastia and obesity with fat deposits for the female type are a result of relative hyperestrogenemia [7]. In the KS patients this may lead to an increased incidence of female predominant autoimmune disorders [46].

The system biology approaches together pointed to novel aspects of KS phenotypes including perturbed JAK-STAT pathway, dysregulated genes important for disturbed immune system (IL4), energy balance (POMC and LEP) and erythropoietin signaling in KS. Sex chromatin is detected in $80 \%$ of the patients with KS. Modified laboratory parameters: decreased testosterone in the blood and urinary excretion of 17-ketosteroids; an increase in the amount of estrogen in the plasma, as well as their excretion with urine; high levels of gonadotropins in plasma, especially follitropin, are observed. Biopsy of testicles should be used due to the inaccuracy of laboratory parameters (hyalinosis of the walls of seminal tubules, aplasia of the generative epithelium, aspermia). Usually KS males present a normal growth hormone - insulin-like growth factor IGF-I axis and increased luteinizing hormone and folliclestimulating hormone levels due to their androgen deficiency [17]. However, early diagnosis of sex chromosome syndromes may provide better development and quality of life for patients with these disorders. Samango-Sprouse et al. [47] observed significant advantages in the cognition, language, intellectual, and psychomotor functions of the patients with KS treated with hormone therapy at 3-6 years of age compare to a group of untreated patients.

The double aneuploidy $48, X X Y,+21$ was first described in 1959, and the incidence is reported to be 0.4 to 0.9 per 10,000 male births $[9,47$, 48]. Most commonly, double aneuploidy occurs when two meiotic nondisjunction events happen from the same or different parental origins. The coincidence rate of DS and KS in the same patient is $0.098 \%$ in newborns, and it has been found to dependent on parental age. Advanced maternal age is one of the main risk factors for double aneuploidy, as it is for single chromosomal aneuploidies caused by parental nondisjunction during gametogenesis [49-51]. The nonrandom aspect of double aneuploidy provides evidence that a hereditary predisposition to nondisjunction exists, with one chromosomal imbalance increasing the risk of another to occur [52]. The phenotype of $48, X X Y,+21$ double aneuploidy is characterized by classical DS features in children, who then develop additional KS symptoms from the age of puberty [9, 52]. Since the sexual development primarily depends on the presence of the $Y$ chromosome, the $48, X X Y,+21$ individuals have male phenotype. $\mathrm{KS}$ is a form of primary testicular failure with testicular hypotrophy and elevated gonadotropin plasma levels, and it is the most common form of male hypogonadism [53]. In addition, the spectrum of different mental problems could be wider, and their risk could be higher in this group of patients. In cases of combined DS and KS the incidence of congenital heart disease could be higher compare to the isolated forms of these aneuploidies. Sevcan Tug Bozdogan and Atil Bisgin reported of DownKlinefelter syndrome with accompanying both heart defects and hypothyroidism [49]. 
The combination of DS and TS is very rare (1 in $2,000,000)[15,54]$. Evren Gumus observed a two-year old girl with karyotype from the peripheral lymphocytes using G-bandings "mos45,X[41]/47,XX,+21[59]". She had stigmata's such as up slant palpebral fissures, brachycephaly and epicanthus, renal hypoplasia and hepatomegaly. In this case, at early ages, the clinical picture is completely compatible with the autosomal chromosome aneuploidy, but the phenotypic effects of TS will become dominant in post pubertal period [15].

Therefore, Down-Klinefelter and Down-Turner syndromes are rare chromosomal abnormalities. A patient present with physical characteristics of DS at birth but KS or TS features during puberty. It is important to counsel families about recurrence risk for future pregnancies. A clinical geneticist evaluation is also recommended.

\section{Conclusions}

Cytogenetic variants of Down syndrome are simple complete trisomy 21 , translocation form and mosaicism. Trisomy 21 is associated with advanced maternal age. Phenotypic manifestations of Down syndrome are associated with the locus 21q22. The maternal and parental nondisjunction of X-chromosomes in meiosis causes Klinefelter and Turner syndromes. These chromosomal diseases are variants of intersexualism with intermediate chromosomal sex. Down-Klinefelter and Down-Turner syndromes are double aneuploidies. Patients at birth have a Down syndrome phenotype, and signs of Klinefelter and Turner syndromes appear during puberty. Diagnosis of aneuploidy is based on the cytogenetic investigation (karyotyping), DNA analysis, ultrasonography and biochemical markers of chromosomal pathology.

\section{Funding}

This research received no external funding.

\section{Conflict of Interests}

The authors declare no conflict of interest.

\section{Author Contributions}

Bihunyak T.V. - conceptualization, writing original draft; Bondarenko Yu.I. - supervision; Kulyanda O.O. - writing - review and editing; Charnosh S.M. - formal analysis; Sverstiuk A.S. software; Bihuniak K.O. - validation.

\section{ХРОМОСОМНІ ЗАХВОРЮВАННЯ В ПАТОЛОГІЇ ЛЮДИНИ (огЛЯД Літератури) \\ *Т.В. Бігуняк, Ю.І. Бондаренко, О.О. Кулянда, С.М. Чарнош, А.С. Сверстюк, К.О.Бігуняк}

ТЕРНОПІЛЬСЬКИЙ НАЦІОНАЛЬНИЙ МЕДИЧНИЙ УНІВЕРСИТЕТ ІМЕНІ І.Я. ГОРБАЧЕВСЬКОГО, ТЕРНОПІЛЬ, УКРАЇНА

Вступ. Хромосомні захворювання є причиною 45-50 \% множинних вроджених вад. Основні дослідження мутацій - це використання геномних технологій для виявлення співвідношення генотипу та фенотипу при анеуплоїдіях та розуміння їх патогенезу.

Мета. Метою дослідження $\epsilon$ вивчення етіології, патогенезу симптомів та методів діагностики пацієнтів із синдромами Дауна, Клайнфельтера, Тернера та подвійними анеуплоїдіями 21 та статевих хромосом.

Методи. Був проведений пошук за ключовими словами "синдром Дауна", "синдром Клайнфельтера", "синдром Тернера", "подвійна анеуплоїдія" публікацій за період 2000-2020 років.

Результати. Синдроми Дауна, Клайнфельтера та Тернера є найпоширенішими анеуплоїдіями серед життєздатних новонароджених. Частота мейотичних нерозходжень, які спричиняють ці анеуплоїдіі, зростає з віком жінки. Ідентифіковані гени, які відповідають за патогенез симптомів при синдромах трисомії 21, Тернера та Клайнфельтера. Діагностика хромосомних захворювань включає програми пренатального скринінгу та постнатальне тестування.

Висновки. Цитогенетичні варіанти синдрому Дауна - це проста повна трисомія 21, транслокаційна та мозаїчна форми. Трисомія 21 асоціюється із збільшенням віку матері. Фенотипові прояви синдрому Дауна пов'язані з локусом 21q22. Материнське та батьківське нерозходження Х-хромосом при мейозі спричиняє синдроми Клайнфельтера та Тернера. Ці хромосомні захворювання є варіантами інтерсексуалізму з проміжною хромосомною статтю. Синдроми Дауна-Клайнфельтера та Дауна-Тернера $\epsilon$ подвійними анеуплоїдіями. Пацієнти при народженні мають фенотип синдрому Дауна, а ознаки синдромів Клайнфельтера та Тернера з'являються у період статевого дозрівання. Діагностика анеуплоїдій грунтується на цитогенетичному дослідженні (каріотипуванні), аналізі ДНК, ультрасонографії та біохімічних маркерах хромосомної патології.

КЛЮЧОВІ СЛОВА: синдром Дауна; синдром Клайнфельтера; синдром Тернера; подвійна анеуплоїдія. 


\section{Інформація про авторів}

Бігуняк Тетяна Володимирівна - кандидат медичних наук, доцент кафедри патологічної фізіології Тернопільського національного медичного університету імені І.Я. Горбачевського МОЗ України

Бондаренко Юрій Іванович - доктор медичних наук, професор кафедри патологічної фізіології Тернопільського національного медичного університету імені І.Я. Горбачевського МОЗ України

Кулянда Олена Олегівна - кандидат медичних наук, доцент кафедри патологічної фізіології Тернопільського національного медичного університету імені І.Я. Горбачевського МОЗ України

Чарнош Софія Михайлівна - кандидат медичних наук, доцент кафедри патологічної фізіології Тернопільського національного медичного університету імені І.Я. Горбачевського МОЗ України

Сверстюк Андрій Степанович - кандидат технічних наук, доцент кафедри медичної інформатики Тернопільського національного медичного університету імені І.Я. Горбачевського МОЗ України

Бігуняк Катерина Олегівна - студентка 6 курсу медичного факультету Тернопільського національного медичного університету імені І.Я. Горбачевського МОЗ України

\section{Information about the author}

Bihunyak T.V. - MD, Ph.D., Associate Professor, Department of Pathophysiology, I. Horbachevsky Ternopil National Medical University, Ternopil, Ukraine.

ORCID https://orcid.org/0000-0002-4985-5443, e-mail: bihunyak@tdmu.edu.ua

Bondarenko Yu.I. - MD, Ph.D., Professor, Department of Pathophysiology, I. Horbachevsky Ternopil National Medical University, Ternopil, Ukraine.

ORCID https://orcid.org/0000-0003-2681-5526, e-mail: bondarenkoui@tdmu.edu.ua

Kulyanda 0.0. - Department of Pathophysiology, I. Horbachevsky Ternopil National Medical University, Ternopil, Ukraine.

ORCID https://orcid.org/0000-0001-6197-9046, e-mail: kulyanda_olol@tdmu.edu.ua

Charnosh S.M. - MD, Ph.D., Associate Professor, Department of Pathophysiology, I. Horbachevsky Ternopil National Medical University, Ternopil, Ukraine.

ORCID https://orcid.org/0000-0001-9827-8024, e-mail: charnoshsm@tdmu.edu.ua

Sverstiuk A.S. - PhD, Associate Professor, Department of Medical Informatics, I. Horbachevsky Ternopil National Medical University, Ternopil, Ukraine.

ORCID https://orcid.org/0000-0001-8644-0776, e-mail: sverstyuk@tdmu.edu.ua

Bihuniak K.O. $-6^{\text {th }}$ year student of the Faculty of Medicine, I. Horbachevsky Ternopil National Medical University, Ternopil, Ukraine.

\section{References}

1. Bihunyak TV Current views on the causes and phenotypic manifestations of Down syndrome. The achievements of Clinical and Experimental medicine. 2008;1(8):7-11.

2. Protsyuk OV, Lynchak OV, Pokanevich TM Prevalence of chromosomal abnormalities among live births and stillbirths in Ukraine. Obstetrics. Gynecology. Genetics. 2017;3:37-41.

3. Kazemi M, Salehi M, Kheirollahi M Down Syndrome: Current Status, Challenges and Future Perspectives. Int J Mol Cell Med Summer. 2016; Vol 5 No 3:125-33.

4. Mathew AK, Amaladas AS, Ahmed A, Hameed S. Clinical Presentation of Down's syndrome: A case report. The journal of medical research. 2017;3(3):107-9. doi: 10.31254/jmr.2017.3304

5. Shankar RK, Backeljauw PF. Current best practice in the management of Turner syndrome. Therapeutic Advances in Endocrinology and Metabolism. 2018;9(1): 33-40.

doi: $10.1177 / 2042018817746291$

6. Souza MP, Santos SM, Lima MM, Machado JM, Melo MM, Oliveira EH, Guerreiro JF. Chromosomal analyses in genetic counseling of patients with developmental and congenital abnormalities from Belém, Pará State, Brazil: a retrospective study of 17 years. doi: 10.5123/S2176-6223201901597

7. Bihunyak TV Hereditary syndromes of intersexualism with an intermediate chromosomal sex. The achievements of Clinical and Experimental medicine. 2008;2(9):9-14.

8. Chebel Z, Krayem S, Nassif Y, et al. When Edwards meets Klinefelter: a new case of double Aneuploidy. J Pediatr Neonatal Care. 2019;9(2):65-6.

9. Pinti E, Lengyel A, Fekete $G$, et al. What should we consider in the case of combined Down- and $47, X Y,+i(X)(q 10)$ Klinefelter syndromes? The unique case of a male newborn and review of the literature. BMC Pediatrics. 2020;20:17.

doi: 10.1186/s12887-019-1905-9

10. Lan RY, Chou CT, Wang PH, Chen RC, $\mathrm{Hsiao} \mathrm{CH}$. Trisomy 21 screening based on first and second trimester in a Taiwanese population. Taiwanese Journal of Obstetrics and Gynecology. 2018 Aug $1 ; 57(4): 551-4$

doi: 10.1016/j.tjog.2018.06.014 
11. Dooley KJ. Congenital Heart Disease and Down Syndrome In: Rubin IL, Merrick J, Greydanus $D E$, et al., editors. Health Care for People with Intellectual and Developmental Disabilities across the Lifespan: Springer. 2016:1301-10.

doi: 10.1007/978-3-319-18096-0_105

12. English C, Hammersley AL, Jackson A, Stenhouse $\mathrm{S}$, Cross IE. Recurrent trisomy 21 resulting from gonadal mosaicism. Journal of Medical Genetics. 2001.

13. Coppedè F. Risk factors for Down syndrome. Archives of toxicology. 2016 Dec;90(12):2917-29.

doi: 10.1007/s00204-016-1843-3

14. PLAIASU V. Down syndrome-genetics and cardiogenetics. Maedica. 2017 Sep;12(3):208-13.

15. Gumus E. Two Rare Variants of Down Syndrome: Down-Turner Syndrome and Down Syndrome with Translocation $(13 ; 14)$ : A Case Report. Iranian Journal of Public Health. 2019 Nov;48(11):2079-82.

doi: 10.18502/ijph.v48i11.3529

16. Zaki MS, Kamel AA, El-Ruby M. Double aneuploidy in three Egyptian patients: Down-Turner and Down-Klinefelter syndromes. Genetic counseling 2005 Jan 1;16(4):393-402.

17. Belling $K$, Russo $F$, Jensen $A B$, Dalgaard MD, Westergaard D, Rajpert-De Meyts E, Skakkebæk NE, Juul A, Brunak S. Klinefelter syndrome comorbidities linked to increased $X$ chromosome gene dosage and altered protein interactome activity. Human Molecular Genetics. 2017 Apr 1;26(7):1219-29.

doi: $10.1093 / \mathrm{hmg} / \mathrm{ddx} 014$

18. Gnetetskaya VA, Kurtser MA, Malmberg OL. Early diagnosis of fetal chromosomal pathology using the OSCAR program. Obstetrics and Gynecology. 2010;1:24-8.

19. Shargorodska EB. A retrospective evaluation of the condition of newborns with congenital heart defects. Lviv Medical Journal Acta Medica Leopoliensia. 2018;24(3):52-7.

doi: 10.25040/aml2018.03.052

20. Marder L, Tulloh R, Pascall E. Cardiac problems in Down syndrome. Paediatrics and Child Health. 2015 Jan 1;25(1):29.

doi: 10.1016/j.paed.2014.07.011

21. Jacobs EG, Leung MP, Karlberg J. Distribution of symptomatic congenital heart disease in Hong Kong. Pediatric cardiology. 2000 Mar 1;21(2):148-57. doi: $10.1007 / s 002469910025$

22. Kim MA, Lee YS, Yee NH, Choi JS, Choi JY, Seo K. Prevalence of congenital heart defects associated with Down syndrome in Korea. Journal of Korean Medical Science. 2014 Nov 1;29(11):1544-9. doi: $10.3346 / j k m s .2014 .29 .11 .1544$

23. de Rubens Figueroa J, del Pozzo Magaña B, Pablos Hach JL, Calderón Jiménez C, Castrejón Urbina R. Heart malformations in children with Down syndrome. Revista Española de Cardiología (English Edition). 2003 Sep 1;56(9):894-9.

doi: 10.1016/s0300-8932(03)76978-4

24. Vida VL, Barnoya J, Larrazabal LA, Gaitan G, de Maria Garcia F, Castañeda AR. Congenital cardiac disease in children with Down's syndrome in Gua- temala. Cardiology in the Young. 2005 Jun;15(3): 286-90.

doi: 10.1017/s1047951105000582

25. Elmagrpy Z, Rayani A, Shah A, et al. Down syndrome and congenital heart disease: why the regional difference as observed in the Libyan experience? Cardiovasc J Afr. 2011;22:306-9.

doi: 10.5830/cvja-2010-072

26. Barlow GM, Chen XN, Shi ZY, Lyons GE, Kurnit DM, Celle L, Spinner NB, Zackai E, Pettenati MJ, Van Riper AJ, Vekemans MJ. Down syndrome congenital heart disease: a narrowed region and a candidate gene. Genetics in Medicine. 2001 Mar;3(2):91101.

doi: 10.1097/00125817-200103000-00002

27. Calkoen EE, Hazekamp MG, Blom NA, Elders BB, Gittenberger-de Groot AC, Haak MC, Bartelings MM, Roest AA, Jongbloed MR. Atrioventricular septal defect: From embryonic development to long-term follow-up. International journal of cardiology. 2016 Jan 1;202:784-95.

doi: 10.1016/j.ijcard.2015.09.081

28. Ackerman C, Locke AE, Feingold E, Reshey B, Espana K, Thusberg J, Mooney S, Bean LJ, Dooley KJ, Cua $\mathrm{CL}$, Reeves $\mathrm{RH}$. An excess of deleterious variants in VEGF-A pathway genes in Down-syndromeassociated atrioventricular septal defects. The American Journal of Human Genetics. 2012 Oct 5;91(4): 646-59.

doi: 10.1016/j.ajhg.2012.08.017

29. Mateos MK, Barbaric D, Byatt SA, Sutton R, Marshall GM. Down syndrome and leukemia: insights into leukemogenesis and translational targets. Translational pediatrics. 2015 Apr;4(2):76-92.

doi: $10.3978 /$ j.issn.22244336.2015.03.03

30. Sobey CG, Judkins CP, Sundararajan V, Phan TG, Drummond GR, Srikanth VK. Risk of major cardiovascular events in people with Down syndrome. PloS one. 2015 Sep 30;10(9):e0137093.

doi: 10.1371/journal.pone.0137093

31. Matthews-Brzozowska T, Cudziło D, Walasz J, Kawala B. Rehabilitation of the orofacial complex by means of a stimulating plate in children with Down syndrome. Adv Clin Exp Med. 2015 Mar 1;24(2):301-5. doi: 10.17219/acem/40451

32. Sixou JL, Vernusset N, Daigneau A, Watine D, Marin L. Orofacial therapy in infants with Down syndrome. Journal of Dentofacial Anomalies and Orthodontics. 2017;20(1):108.

doi: 10.1051/odfen/2016038

33. Radoi VE, Bohiltea CL, Bohiltea RE, Albu DN. Cell free fetal DNA testing in maternal blood of Romanian pregnant women. Iranian journal of reproductive medicine. 2015 Oct;13(10):623-6.

34. Smith-Bindman R, Miglioretti DL, Sentilhes L, Salomon LJ, Vayssière C, Norton ME, Wapner RJ. Cellfree DNA analysis for noninvasive examination of trisomy. New England Journal of Medicine. 2015 Dec 24;373(26):2581-2.

doi: $10.1056 /$ nejmc1509344

35. Meck JM, Dugan EK, Matyakhina L, Aviram A, Trunca C, Pineda-Alvarez D, Aradhya S, Klein RT, 
Cherry AM. Noninvasive prenatal screening for aneuploidy: positive predictive values based on cytogenetic findings. American journal of obstetrics and gynecology. 2015 Aug 1;213(2):214 e1-214 e5.

doi: 10.1016/j.ajog.2015.04.001

36. Taylor-Phillips S, Freeman K, Geppert J, Agbebiyi A, Uthman OA, Madan J, Clarke A, Quenby S, Clarke A. Accuracy of non-invasive prenatal testing using cell-free DNA for detection of Down, Edwards and Patau syndromes: a systematic review and metaanalysis. BMJ open. 2016 Jan 1;6(1).

doi: 10.1136/bmjopen-2015-010002

37. Fedorova NI, Tetruashvili NK, Demura TA et al. Importance of embryonic cells isolated from the cervical canal in early non-invasive prenatal diagnosis. Obstetrics and Gynecology 2010;1:28-31.

38. Linglart A, Cabrol S, Berlier P, Stuckens C, Wagner KD, De Kerdanet M, Limoni C, Carel JC, Chaussain JL. Growth hormone treatment before the age of 4 years prevents short stature in young girls with Turner syndrome. European journal of endocrinology. 2011 Jun 1;164(6):891-7.

doi: $10.1530 /$ eje-10-1048

39. Gravholt $\mathrm{CH}$, Andersen $\mathrm{NH}$, Conway GS, Dekkers OM, Geffner ME, Klein KO, Lin AE, Mauras N, Quigley CA, Rubin K, Sandberg DE. Clinical practice guidelines for the care of girls and women with Turner syndrome: proceedings from the 2016 Cincinnati International Turner Syndrome Meeting. European journal of endocrinology. 2017 Sep 1;177(3):G1-70. doi: 10.1530/eje-17-0430

40. Knauer-Fischer S, Besikoglu B, Inta I, Kneppo C, Vogt PH, Bettendorf M. Analyses of gonadoblastoma $Y$ (GBY)-locus and of $Y$ centromere in Turner syndrome patients. Experimental and Clinical Endocrinology \& Diabetes. 2015 Jan;123(01):61-5. doi: $10.1055 / \mathrm{s}-0034-1387734$

41. Lunding SA, Aksglæde L, Anderson RA, Main KM, Juul A, Hagen CP, Pedersen AT. AMH as predictor of premature ovarian insufficiency: a longitudinal study of 120 Turner syndrome patients. The Journal of Clinical Endocrinology \& Metabolism. 2015 Jul 1;100(7):E1030-8.

doi: $10.1210 /$ jc.2015-1621

42. Zaiem F, Alahdab F, Al Nofal A, Murad MH, Javed $A$. Oral versus transdermal estrogen in turner syndrome: a systematic review and meta-analysis. Endocrine Practice. 2017 Apr;23(4):408-21.

doi: 10.4158/ep161622.or

43. Lanfranco F, Kamischke A, Zitzmann M, Nieschlag E. Klinefelter's syndrome. The Lancet. 2004 Jul 17;364(9430):273-83.

doi: 10.1016/S0140-6736(04)16678-6

44. Kondo T, Kuroda S, Usui K, et al. A case of a rare variant of Klinefelter syndrome, 47,XY,i(X)(q10). Andrologia. 2018;17:e13024. doi: $10.1111 /$ and.13024
45. Dürrbaum M, Storchova Z. Effects of aneuploidyon gene expression: implications for cancer. FEBSJ. 2016; 283,791-802.

doi: $10.1111 /$ febs. 13591

46. Seminog OO, Seminog AB, Yeates D, Goldacre MJ. Associations between Klinefelter's syndrome and autoimmune diseases: English national record linkage studies. Autoimmunity. 2015 Feb 17;48(2): 125-8.

doi: $10.3109 / 08916934.2014 .968918$

47. Samango-Sprouse CA, Sadeghin T, Mitchell FL, Dixon T, Stapleton E, Kingery M, Gropman AL. Positive effects of short course androgen therapy on the neurodevelopmental outcome in boys with 47, $X X Y$ syndrome at 36 and 72 months of age. American Journal of Medical Genetics Part A. 2013 Mar;161(3): 501-8.

doi: 10.1002/ajmg.a.35769

48. Bozdogan ST, Bisgin A. A rare double aneuploidy case (Down-Klinefelter). Journal of pediatric genetics. 2017 Dec;6(4):241-3.

doi: $10.1055 / \mathrm{s}-0037-1604098$

49. Bozdogan ST, Bisgin A. A rare double aneuploidy case (Down-Klinefelter). Journal of pediatric genetics. $2017 \mathrm{Dec} ; 6(4): 241-3$.

doi: $10.1055 / \mathrm{s}-0037-1604098$

50. Shen Z, Zou CC, Shang SQ, Jiang KW. DownKlinefelter syndrome $(48, X X Y,+21)$ in a child with congenital heart disease: case report and literature review. Internal Medicine. 2012;51(11):1371-4.

doi: 10.2169/internalmedicine.51.7097

51. Kovaleva NV, Mutton DE. Epidemiology of double aneuploidies involving chromosome 21 and the sex chromosomes. American Journal of Medical Genetics Part A. 2005 Apr 1;134(1):24-32.

doi: 10.1002/ajmg.a.30306

52. Jeanty $C$, Turner $C$. Prenatal diagnosis of double aneuploidy, $48, X X Y,+21$, and review of the literature. Journal of Ultrasound in Medicine. 2009 May;28(5):673-81.

doi: 10.7863/jum.2009.28.5.673

53. Akgul M, Ozkinay F, Ercal D, Cogulu O, Dogan O, Altay B, Tavmergen E, Gunduz C, Ozkinay C. Cytogenetic abnormalities in 179 cases with male infertility in Western Region of Turkey: report and review. Journal of assisted reproduction and genetics. 2009 Mar 1;26(2-3):119-22.

doi: 10.1007/s10815-009-9296-8

54. Manassero-Morales G, Alvarez-Manassero D, Merino-Luna A. Down-Turner syndrome: A case with double monoclonal chromosomal abnormality. Case reports in pediatrics. 2016 Jan 1;2016.

doi: $10.1155 / 2016 / 8760504$

Received 24 Mar 2020; revised 14 May 2020; accepted 05 June 2020.

This is open access article distributed under the Creative Commons Attribution License, which permits unrestricted use, distribution, and reproduction in any medium, provided the original work is properly cited. 